

\title{
Adaptive sales \& operations planning: Innovative concept for manufacturing collaborative decisions?
}

Jean-Baptiste Vidal, Matthieu Lauras, Jacques Lamothe, Romain Miclo

\section{To cite this version:}

Jean-Baptiste Vidal, Matthieu Lauras, Jacques Lamothe, Romain Miclo. Adaptive sales \& operations planning: Innovative concept for manufacturing collaborative decisions?. 19th Working Conference on Virtual Enterprises (PRO-VE), Sep 2018, Cardiff, United Kingdom. p.362-374, 10.1007/978-3-31999127-6_31.hal-01885026

\section{HAL Id: hal-01885026 https://imt-mines-albi.hal.science/hal-01885026}

Submitted on 9 Jul 2019

HAL is a multi-disciplinary open access archive for the deposit and dissemination of scientific research documents, whether they are published or not. The documents may come from teaching and research institutions in France or abroad, or from public or private research centers.
L'archive ouverte pluridisciplinaire HAL, est destinée au dépôt et à la diffusion de documents scientifiques de niveau recherche, publiés ou non, émanant des établissements d'enseignement et de recherche français ou étrangers, des laboratoires publics ou privés. 


\title{
Adaptive Sales \& Operations Planning: Innovative Concept for Manufacturing Collaborative Decisions?
}

\author{
Jean-Baptiste Vidal ${ }^{1}$, Matthieu Lauras ${ }^{2}$, Jacques Lamothe ${ }^{2}$ and Romain Miclo ${ }^{3}$ \\ ${ }^{1}$ University of Orléans, IUT, Orléans, France \\ jean-baptiste.vidal@univ-orleans. fr \\ ${ }^{2}$ IMT Mines Albi, Industrial Engineering Department, Albi, France \\ \{matthieu.lauras, jacques.lamothe\}@mines-albi.fr \\ ${ }^{3}$ AGILEA Conseil, Toulouse, France \\ romain.miclodagilea.fr
}

\begin{abstract}
By definition, Supply Chain Management includes a huge number of collaborative decision processes. In a manufacturing environment, the Sales \& Operations Planning (S\&OP) process is often used to support strategic and tactical decisions such as recruitment, investment on machines or subcontracting. S\&OP was invented in the eighties when collaboration issues between and within companies were radically different from what obtains today. Many rules and opportunities that are important for manufacturing collaborative decisions have changed but not in this process. Recently, the Demand Driven Institute has developed the Demand Driven Adaptive Enterprise system that includes an innovative process called Adaptive S\&OP. The purpose of this paper is to develop a structured comparison between the traditional S\&OP and the new Adaptive S\&OP, to objectively characterize their differences, and to highlight points of vigilance regarding future Adaptive S\&OP implementations. Based on this analysis, some suggestions for future research works are made.
\end{abstract}

Keywords: Manufacturing Collaborative Decisions, Sales \& Operations Planning, Adaptive Sales \& Operations Planning, Comparison Framework, Supply Chain Management, Demand Driven Adaptive Enterprise.

\section{Introduction and Research Question}

Sales \& Operations Planning is probably the most popular collaborative process for supporting strategic and tactical decisions in manufacturing environment. Designed more than 30 years ago, this process is regularly enriched and criticized in the Supply Chain literature [6]. Notably, scholars point out that this process is not necessarily applied as it should be and not necessarily adapted for the current organizational networks, which have changed a lot during the last decades. Parallelly, some authors have recently suggested some new paradigms and approaches to manage material flows within and between companies. This is essentially the case of what is called Demand Driven Adaptive Enterprise system [12]. In this system, one of the pillars is called Adaptive Sales \& Operations Planning (AS\&OP) and the authors affirm that this can address the limits and weaknesses of the current S\&OP processes. The purpose of this research is to compare the traditional S\&OP process with this new AS\&OP process in 
order to know whether AS\&OP is a really innovative contribution for collaborative decisions in a manufacturing environment. The objective of this analysis is also to highlight some points of vigilance on AS\&OP that should be further studied.

The paper is divided into four complementary sections. The first one discusses some key points in the literature on this topic. The second one develops a structured framework that can be used to compare processes in terms of both objective and coordination issues. The third section develops a discussion based on these comparisons while the last section gives a rapid conclusion on this research work.

\section{Background}

\subsection{Manufacturing Collaborative Decisions}

Managing a manufacturing plant entails making decisions at different levels: strategic, tactical and operational. For decades, decision-makers use the Manufacturing Resource Planning (MRP II) system to support their decisions [16]. This system is a cascading planning system that offers a set of planning process for each decision level. Regarding the strategic and tactical levels, MRP II is executed through the Sales and Operations Planning (S\&OP). This was made to support collaboration between the different stakeholders of a company (finance, sales, production, logistics, supply, etc.) regarding decisions such as recruitment, investment on machines or subcontracting. Definitively, MRP II and S\&OP have brought benefits to companies during decades. But these tools seem now to become obsolete as the economic rules and environment have drastically changed [13]. Consequently, there has emerged recently from the corporate world a fundamental rethinking of the MRP II logic - a rethinking that draws on elements of developments such as Lean Systems and Theory of Constraints to improve the overall performance of manufacturing operations and collaborative mechanisms. This rethinking has resulted in a new approach - Demand Driven Adaptive Enterprise [12].

\section{2 "Sales \& Operations Planning"}

Richard C. Ling [4] is recognized by academics and practitioners as the father of S\&OP in the late 1980s. Since his first model of the process [5], S\&OP was popularized by practitioners through the exchanges of best practices in the supply chain community such as APICS. The APICS defines S\&OP as "A process to develop tactical plans that provide management the ability to strategically direct its businesses to achieve competitive advantage on a continuous basis by integrating customer-focused marketing plans for new and existing products with the management of the supply chain. The process brings together all the plans for the business (sales, marketing, development, manufacturing, sourcing, and financial) into one integrated set of plans". This definition underlines the collaborative nature of S\&OP so that all the company's functions generate an aligned business plan.

Practitioners tried to standardize this process in order to implement it in different business activities. Fig. 1. shows the five-step common approach accepted as traditional 
in business activities [6]. The goals of S\&OP are easy to understand, but practitioners in many different companies failed to totally implement this process or did not achieve the expected competitiveness in their markets.

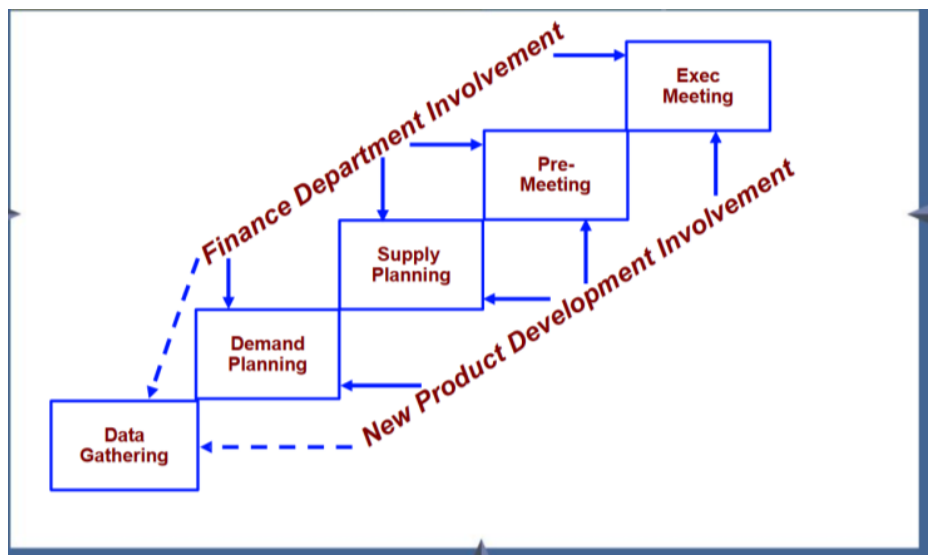

Fig. 1. S\&OP model for practitioners [6]

Considering S\&OP at the supply chain level, Fig. 2. shows a model used during APICS Annual Event 2017. Main boxes fit the Wallace model [6], but they are now detailed and linked to the long-term business objectives. This underlines the idea of practitioners to keep original methodology.

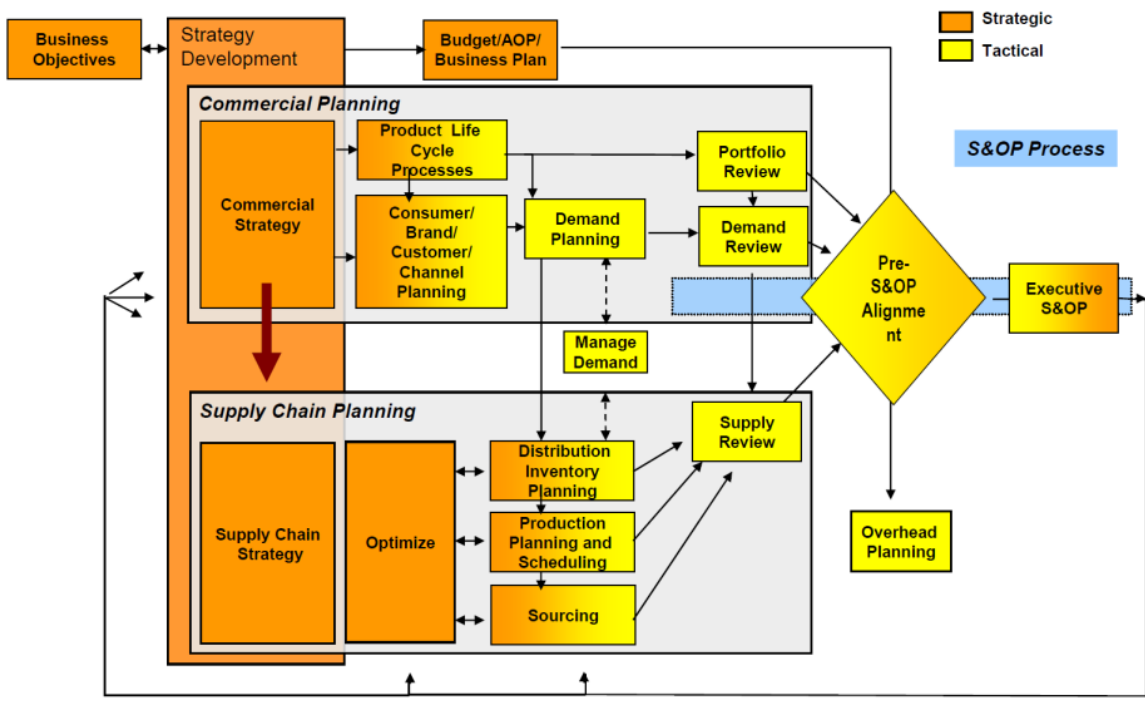

Fig. 2. S\&OP Model by [7]

According to several recent literature reviews [8], [2], [9], the interest of academics for S\&OP has grown since 2000. These literature reviews show two important points: 
- The complexity of the S\&OP process is a reality. Multiple extensions of the original model were proposed and there is now needs to build a common framework for comparison.

- Despite growing research activity, there is a requirement for fine granulometry studies for academics as well as for practitioners.

It is possible to understand that there are multiple reasons for failure when S\&OP is implemented. Despite many improvements and the identification of diverse and numerous success factors [10], S\&OP remains a difficult process to implement [3]. The gap between expected and actual benefits is big [11]. However, practitioners still need answers to their vital problem: balancing supply capabilities with market expectations and needs at a strategic level while generating profit. In an environment where the variety and complexity of products is growing, the time to react is very low, supply chains and markets are spread around the world and customer requirements are very strong, it is more and more difficult to achieve success with the implementation of S\&OP. With this new environment, S\&OP was kept with its initial structure, without major modification. Academics and Practitioners continue to extend and refine the theoretical vision of S\&OP with the aim of identifying the reasons for the failures in reality or the difficulty of reaching a high level of maturity in its implementation: recent research works show that it seems necessary to carry out practical and theoretical studies including contextual impacts [9][11].

\section{3 “Adaptive Sales \& Operations Planning”}

In 2017, the Demand Driven Institute (DDI) created a new approach called Demand Driven Adaptive Enterprise - DDAE [12] based on three major processes:

- $\quad$ Demand Driven Operating Model (DDOM) at the operational level;

- Demand Driven Sales \& Operations Planning (DDS\&OP) at the tactical level;

- $\quad$ Adaptive Sales and Operations Planning (AS\&OP) at the strategic level.

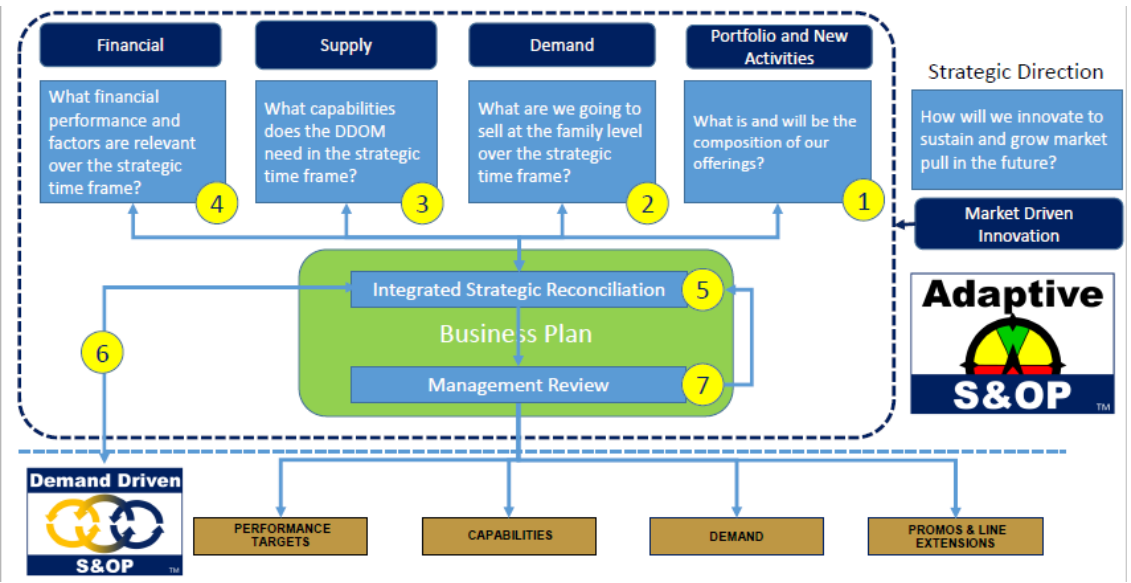

Fig. 3. Model AS\&OP by Demand Driven Institute 
DDAE (the evolution of the first concept DDMRP create by DDI) proposes an integration of multiple approaches such as Lean, Theory of constraint and MRP II. [13] shows that this integrated approach works at the operational level but the demonstration at the strategic level is yet to be done. As the first and second processes have just been assimilated by first practitioners, DDI introduced in 2017 the third AS\&OP process (see Fig. 3.) as a new way to formalize and use the S\&OP philosophy.

\section{Research Questions and Proposal}

\subsection{Research Questions and Assumptions}

Today the number of DDAE practitioners is low in proportion to those practicing S\&OP but the interest of the practitioner community is high. Although the concept of DDAE is recent, there are studies on operational parts of the DDAE model like DDMRP [13], but none of them is based on AS\&OP. As the research on S\&OP is rich [8], as much on the mastered aspects as on those that are yet to be developed, it seems logical to try to compare $\mathrm{S} \& \mathrm{OP}$ and $\mathrm{AS} \& \mathrm{OP}$ by relying on the major features already studied on S\&OP. The corpus of knowledge on DDAE is beginning to be accessible on this subject, through trainings and conferences proposed by the DDI and its global affiliates [12]. Based on this material, we propose in this paper to study the potential of this new collaborative approach by answering two simple research questions:

RQ1: Is AS\&OP really a novelty compared to traditional S\&OP?

RQ2: Which priority aspects of AS\&OP should be studied in future academic research works for supporting efficiently the first implementations?

We considered the following assumptions to conduct this qualitative comparison:

- The two other components of the DDAE system (i.e. DDOM and DDS\&OP) are supposed to be well implemented on the field.

- The study is limited to the public DDAE body of knowledge gathering from DDI white papers [12] and dedicated trainings and conferences.

\subsection{Comparison Framework}

\subsubsection{Create an analysis process}

As underlined by [8], S\&OP is a multifaceted concept. As a result, we used a progressive approach, drawn from different academic journal papers, to design and fulfill a Goal framework and adding points of comparison, step by step, to build a Coordination framework. Fig. 4. shows this analysis process. 


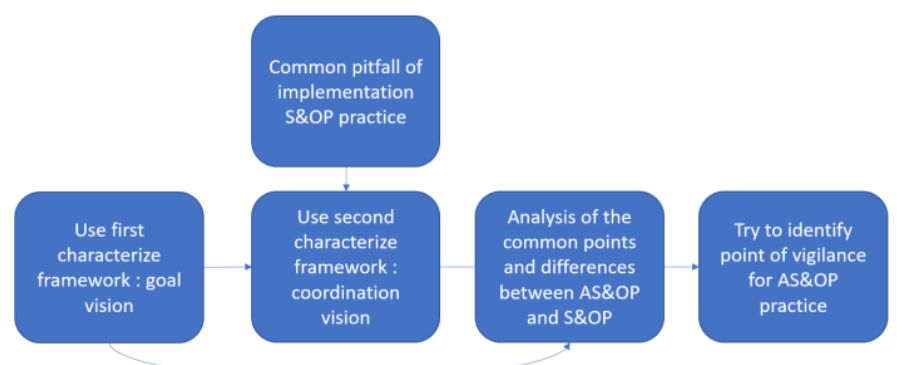

Fig. 4. The process of analysis and synthesis proposed in this paper

Goal-framework: [8] records 5 goals for S\&OP: (i) Produces integrated and functional tactical planning; (ii) Unifies all business plans into one; (iii) Develops a vision from 3 months to 18 months; (iv) Allows alignment between operations and strategy; (v) Generates values and drivers of the company's performance. We will use them to compare S\&OP and AS\&OP. Coordination-framework: four elements will be used to build it to make a comparison between S\&OP and AS\&OP: (i) literature search synthesis framework [8] (ii) Coordination of S\&OP framework [2] (iii) the classical pitfalls of implementing S\&OP in the real world [6], [14] (iv) feedback from a dozen S\&OP implementation experts. The coordination-framework described by [2] defines six principal coordination mechanisms. They are selected to constitute our constructs defined as point of views that are traditionally used by academics and practitioners to describe S\&OP concepts: (i) S\&OP organization; (ii) S\&OP Process; (iii) S\&OP Tools and Data; (iv) Performance management; (v) Strategic alignment; (vi) S\&OP culture and leadership. For each construct, we selected the most convincing analysis axis to make our comparison on the basis of relevant information mainly from [2] and [8]. In the same way, for each analysis axis, we have associated a criterion with 2 or 3 differentiating levels of characterization.

Table. 1. Criteria on S\&OP Coordination

\begin{tabular}{|l|l|l|}
\hline Coord. Constructs & Analysis axis & Criteria \\
\hline \multirow{4}{*}{$\begin{array}{l}\text { S\&OP } \\
\text { organization }\end{array}$} & Stakeholders & $\begin{array}{l}\text { All internal service except finance } \\
\text { All internal service included finance } \\
\text { All internal service included finance and external } \\
\text { suppliers }\end{array}$ \\
\cline { 2 - 3 } & Ritual meeting & $\begin{array}{l}\text { Sporadic and informal meeting } \\
\text { Regular meeting or upon request according to event }\end{array}$ \\
\hline \multirow{5}{*}{ S\&OP Process } & Formalization & $\begin{array}{l}\text { High Level (Macro vision) } \\
\text { Detailed Level (Micro) }\end{array}$ \\
\cline { 2 - 3 } & $\begin{array}{l}\text { Links between } \\
\text { activities }\end{array}$ & $\begin{array}{l}\text { Linear } \\
\text { Nonlinear interconnected }\end{array}$ \\
\cline { 2 - 3 } & Outcome & $\begin{array}{l}\text { Plan production only } \\
\text { Plan sales, production, investment not integrated } \\
\text { Plan sales, production, investment integrated }\end{array}$ \\
\hline \multirow{3}{*}{$\begin{array}{l}\text { S\&OP Tools and } \\
\text { Data }\end{array}$} & IT & $\begin{array}{l}\text { Manual/Spreadsheet } \\
\text { Dedicated IT system }\end{array}$ \\
\cline { 2 - 3 } & $\begin{array}{l}\text { S\&OP data } \\
\text { requirement }\end{array}$ & $\begin{array}{l}\text { Numbers/No Consolidation/No integration } \\
\text { Numbers consolidated and integrated }\end{array}$ \\
\hline
\end{tabular}




\begin{tabular}{|l|l|l|}
\multirow{2}{*}{$\begin{array}{l}\text { Performance } \\
\text { management }\end{array}$} & Metrics & $\begin{array}{l}\text { Cost-based } \\
\text { Flow-based } \\
\text { Production-based }\end{array}$ \\
\cline { 2 - 3 } & KPI's & $\begin{array}{l}\text { Used to perform internal performance only } \\
\text { Used Internal and for Firm Performance, effectiveness of } \\
\text { the S\&OP Process }\end{array}$ \\
\hline $\begin{array}{l}\text { Strategic } \\
\text { alignment }\end{array}$ & $\begin{array}{l}\text { Vertical } \\
\text { alignment/tactical } \\
\text { reconciliation }\end{array}$ & $\begin{array}{l}\text { Disconnected } \\
\text { Effective reconciliation }\end{array}$ \\
\hline \multirow{5}{*}{$\begin{array}{l}\text { S\&OP culture and } \\
\text { leadership }\end{array}$} & $\begin{array}{l}\text { Rewarding and } \\
\text { incentives }\end{array}$ & $\begin{array}{l}\text { Functional incentives with no integration } \\
\text { Collaborative S\&OP enhances integration }\end{array}$ \\
\cline { 2 - 3 } & $\begin{array}{l}\text { Top management } \\
\text { ownership }\end{array}$ & $\begin{array}{l}\text { Low participation of executives } \\
\text { High participation of executives }\end{array}$ \\
\cline { 2 - 3 } & $\begin{array}{l}\text { Change } \\
\text { management }\end{array}$ & $\begin{array}{l}\text { Top-down approach } \\
\text { Bottom-up approach }\end{array}$ \\
\hline
\end{tabular}

The S\&OP concept was created nearly 40 years ago. With the contributions of the practitioners and academics, a theoretical and practical (rather rich) vision of S\&OP can be spread out according to several stages of maturity [15]. Nevertheless, a large number of companies are struggling to go beyond a low maturity stage [3]. To compare S\&OP and AS\&OP, three distinct levels of S\&OP have been identified as a reference: low maturity level of theoretical S\&OP, high maturity level of both theoretical S\&OP and practical S\&OP. Practical S\&OP means the concrete practices observed through the implementation of S\&OP on the knowledge acquired from the feedback of a dozen S\&OP implementation experts. Table. 2. shows the complete characterization framework

Table. 2. Coordination-framework gap analysis

\begin{tabular}{|c|c|c|c|c|c|}
\hline Construct & Analysis axis & $\begin{array}{c}\text { Low Maturity } \\
\text { Level S\&OP } \\
\text { theoretical }\end{array}$ & $\begin{array}{c}\text { High Maturity } \\
\text { Level S\&OP } \\
\text { theoretical }\end{array}$ & S\&OP practice & $\begin{array}{c}\text { High Maturity } \\
\text { Level AS\&OP } \\
\text { theoretical }\end{array}$ \\
\hline \multirow{2}{*}{$\begin{array}{l}\text { S\&OP } \\
\text { organization }\end{array}$} & Stakeholders & $\begin{array}{l}\text { All internal } \\
\text { services except } \\
\text { finance }\end{array}$ & $\begin{array}{l}\text { All internal } \\
\text { services, included } \\
\text { finance and } \\
\text { external suppliers }\end{array}$ & $\begin{array}{l}\text { All internal } \\
\text { services except } \\
\text { finance }\end{array}$ & $\begin{array}{l}\text { All internal } \\
\text { services, included } \\
\text { finance and } \\
\text { external suppliers }\end{array}$ \\
\hline & Ritual meetings & $\begin{array}{l}\text { Sporadic and } \\
\text { informal meetings }\end{array}$ & $\begin{array}{l}\text { Regular meeting or } \\
\text { upon request } \\
\text { according to event }\end{array}$ & & $\begin{array}{l}\text { Regular meetings } \\
\text { or upon request } \\
\text { according to event }\end{array}$ \\
\hline \multirow{3}{*}{ S\&OP Process } & Formalization & $\begin{array}{l}\text { High Level (Macro } \\
\text { vision) }\end{array}$ & $\begin{array}{l}\text { High Level (Macro } \\
\text { vision) }\end{array}$ & $\begin{array}{l}\text { High Level } \\
\text { (Macro vision) }\end{array}$ & $\begin{array}{l}\text { High Level (Macro } \\
\text { vision) }\end{array}$ \\
\hline & Cycle & Linear & Linear & Linear & $\begin{array}{l}\text { Non- Linear } \\
\text { Interconnected }\end{array}$ \\
\hline & Outcome & $\begin{array}{l}\text { Plan sales, } \\
\text { production, } \\
\text { investment not } \\
\text { integrated } \\
\end{array}$ & \begin{tabular}{|l|} 
Plan sales, \\
production, \\
investment \\
integrated \\
\end{tabular} & $\begin{array}{l}\text { Plan production } \\
\text { only }\end{array}$ & \begin{tabular}{|l|} 
Plan sales, \\
production, \\
investment \\
integrated \\
\end{tabular} \\
\hline \multirow[b]{2}{*}{$\begin{array}{l}\text { S\&OP Tools } \\
\text { and Data }\end{array}$} & IT & $\begin{array}{l}\text { Manual/Spreadshe } \\
\text { et }\end{array}$ & $\begin{array}{l}\text { Dedicated IT } \\
\text { system }\end{array}$ & $\begin{array}{l}\text { Manual/Spreads } \\
\text { heet }\end{array}$ & $\begin{array}{l}\text { Dedicated IT } \\
\text { system }\end{array}$ \\
\hline & \begin{tabular}{|l} 
S\&OP data \\
requirement
\end{tabular} & $\begin{array}{l}\text { Numbers/No } \\
\text { Consolidation/No } \\
\text { integration }\end{array}$ & $\begin{array}{l}\text { Numbers } \\
\text { consolidated and } \\
\text { integrated }\end{array}$ & $\begin{array}{l}\text { Numbers/No } \\
\text { Consolidation/N } \\
\text { o integration }\end{array}$ & $\begin{array}{l}\text { Numbers } \\
\text { consolidated and } \\
\text { integrated }\end{array}$ \\
\hline
\end{tabular}




\begin{tabular}{|c|c|c|c|c|c|}
\hline \multirow[b]{2}{*}{$\begin{array}{l}\text { Performance } \\
\text { management }\end{array}$} & Metrics & Cost-based & Cost-based & $\begin{array}{l}\text { Production- } \\
\text { based }\end{array}$ & flow-based \\
\hline & KPI's & $\begin{array}{l}\text { Used to perform } \\
\text { internal } \\
\text { performance only }\end{array}$ & $\begin{array}{l}\text { Used Internal and } \\
\text { for Firm } \\
\text { Performance, } \\
\text { effectiveness of the } \\
\text { S\&OP Process } \\
\end{array}$ & $\begin{array}{l}\text { Used to perform } \\
\text { internal } \\
\text { performance } \\
\text { only }\end{array}$ & $\begin{array}{l}\text { Used Internal and } \\
\text { for Firm } \\
\text { Performance, } \\
\text { effectiveness of the } \\
\text { S\&OP Process } \\
\end{array}$ \\
\hline $\begin{array}{l}\text { Strategic } \\
\text { alignment }\end{array}$ & $\begin{array}{l}\text { Vertical } \\
\text { alignment/tactica } \\
1 \text { reconciliation }\end{array}$ & Disconnected & $\begin{array}{l}\text { Effective } \\
\text { reconciliation }\end{array}$ & Disconnected & $\begin{array}{l}\text { Effective } \\
\text { reconciliation }\end{array}$ \\
\hline \multirow{3}{*}{$\begin{array}{l}\text { S\&OP culture } \\
\text { and leadership }\end{array}$} & $\begin{array}{l}\text { Rewarding and } \\
\text { incentives }\end{array}$ & $\begin{array}{l}\text { Functional } \\
\text { incentives with no } \\
\text { integration }\end{array}$ & $\begin{array}{l}\text { Collaborative } \\
\text { S\&OP enhance } \\
\text { integration }\end{array}$ & $\begin{array}{l}\text { Functional } \\
\text { incentives with } \\
\text { no integration }\end{array}$ & $\begin{array}{l}\text { Collaborative } \\
\text { S\&OP enhance } \\
\text { integration }\end{array}$ \\
\hline & $\begin{array}{l}\text { Top } \\
\text { management } \\
\text { ownership } \\
\end{array}$ & $\begin{array}{l}\text { Low participation } \\
\text { of executives }\end{array}$ & $\begin{array}{l}\text { High participation } \\
\text { of executives }\end{array}$ & $\begin{array}{l}\text { Low } \\
\text { participation of } \\
\text { executives }\end{array}$ & $\begin{array}{l}\text { High participation } \\
\text { of executives }\end{array}$ \\
\hline & $\begin{array}{l}\text { Change } \\
\text { management }\end{array}$ & $\begin{array}{l}\text { Top-down } \\
\text { approach }\end{array}$ & $\begin{array}{l}\text { Bottom-up } \\
\text { approach }\end{array}$ & $\begin{array}{l}\text { Top-down } \\
\text { approach }\end{array}$ & $\begin{array}{l}\text { Bottom-up } \\
\text { approach }\end{array}$ \\
\hline
\end{tabular}

To study S\&OP practices we used classical pitfalls reported by practitioners about S\&OP [6], [14] that have been classified in our selected points of view:

- S\&OP organization: The strategic players of the company think that only the supply chain and the production are concerned by this process; the meeting monthly loses its meaning in the eyes of the main actors: no decisions made, short-term management only, too much details, search for the culprit; no integration of suppliers' or customers' vision;

- S\&OP Process: lack of formal processes about S\&OP meeting, no formal approach to link tactical and strategic decisions;

- S\&OP Tools and Data: product life stages are not considered, lack of data accuracy or gathering;

- Performance management: the actors focus on the short-term objectives and do not consider the possibility of taking important decisions regarding the future of the business. They focus on only one goal: "establish a demand forecast instead of other key issues concerning S\&OP";

- Strategic alignment: Strategy alignment is dysfunctional as it is not shared between company functions;

- S\&OP culture and leadership: The S\&OP team does not try to avoid conflict neither to monitor the efficiency of the S\&OP process and to improve the company.

\subsection{Gap Analysis}

\subsubsection{Goal-framework:}

Through the test-one, AS\&OP principles [12] seem to cover all the different points that are usually identified in a traditional S\&OP. We conclude that an AS\&OP can be assimilated to a type of S\&OP as academics and practitioners usually describe it.

3.3.2 Coordination-framework:

On this dimension, the comparison was done based on data available in [12] for the 
AS\&OP, in [2], [3], [8], [9] for the theoretical S\&OP and in [6] and our knowledge acquired by interviews with dozens of S\&OP implementation experts for the practical S\&OP. Table 2 shows the results.

\section{Discussion and Research Agenda}

\subsection{Comparison between High Level Maturity S\&OP and AS\&OP}

First of all, we compare the result between the column "high maturity level" and AS\&OP. We observe two discordant elements in this comparison: S\&OP Process and Performance Management. The other ones are not discriminating.

The first difference refers to the non-linearity of the AS\&OP process as described in [12]. Fig. 5. shows that the processes (1.) portfolio and new activities, (2.) demand, (3.) supply and (4.) financial, are considered together to accomplish an (5.) integrated strategic reconciliation. Practitioners [4] who originally introduced S\&OP recommended to have a cross-functional process with interconnections between all services. This was broken in [6] with the introduction of the pre-meeting step (iv) and the linearization of steps $\mathrm{i}$, ii and iii. AS\&OP finally suggests coming back to the initial approach. The traditional linear approach of S\&OP has made this concept understandable for a wide range of companies but it has also led to set-up failures such as the lack of interest of some of the strategic players concerned other than production and sales. Indeed, a lot of information useful for the coordination of this process is established in a non-linear way, requiring more complex round trips than the present model, with coordination to be agile and permanent between the services. The nonlinear matrix vision of the AS\&OP model can potentially be a best way to success in this coordination point of view, enabling the departments concerned to better find their place according to their real operating rhythm. It is also a difficulty that will have to be overcome particularly in terms of practical organization.

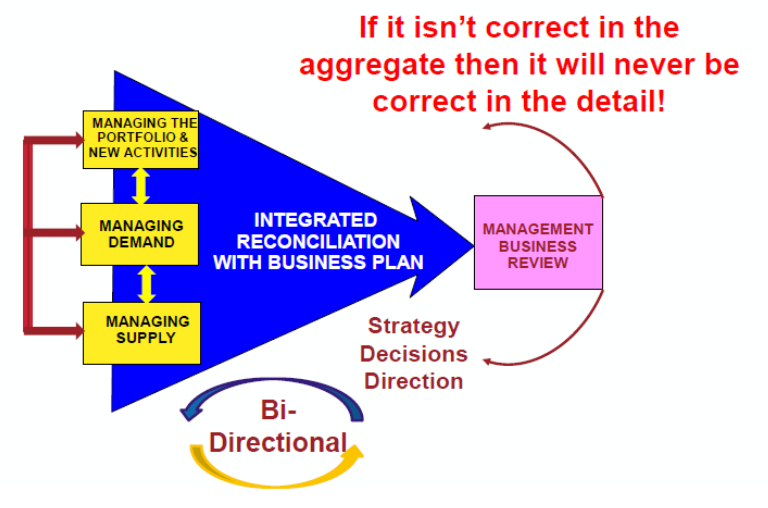

Fig. 5. Evolution of S\&OP by Dick Ling (APICS Event 2016) 
AS\&OP are mainly flow-oriented (i. working capital, ii. contribution margin, iii. customer base). DDI practitioners think that the most important thing is to use relevant information at each level. In that sense, they are inspired by Theory of Constraints and Lean Management philosophy to opt for a flow vision rather than a cost approach.

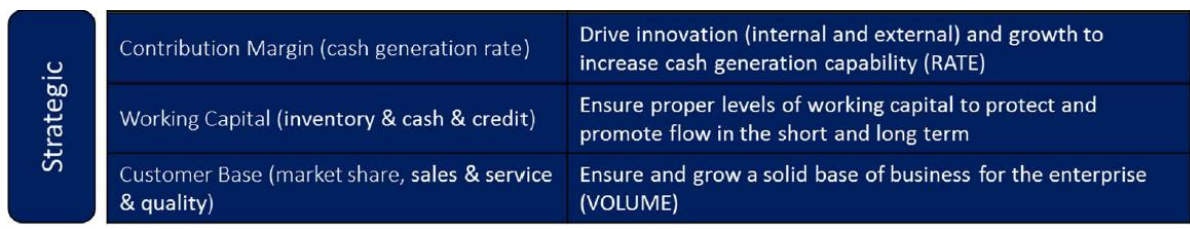

Fig. 6. AS\&OP Strategic KPIs [12]

The goal of S\&OP is to help the coordination of a company's services to make both strategic and tactical decisions for the success of the company. The problem of choosing indicators to drive this process is an important research topic. Traditionally, the practitioners focus on the optimization of the resources until they see only the problem of the capacity versus demand. This constitutes a problem because it ends up concerning only the services of the production and the sales. Consequently, there generally is a disengagement from other departments, with ultimately a malfunction of the S\&OP process. Also, the choice of AS\&OP specific KPIs (see fig. 6.) seems to be a major asset to ensure the success of its implementation.

\subsection{Comparison S\&OP Practices vs AS\&OP}

Let's now compare the results between the columns practical S\&OP and AS\&OP. The idea is to test the ability of the AS\&OP approach (as a whole DDAE) to be implemented efficiently in the field by avoiding the conventional pitfalls of traditional S\&OP. About performance management, AS\&OP used a flow-based metrics as highlighted by DDAE implementation experts. This is not a detail. They explain that the flow approach makes sense to people at the operational and tactical levels (DDOM and DDS\&OP have actually been implemented in several companies). In the early stage of AS\&OP, this can enable to obtain the adherence of top management from each department including sales and finance. A general (success of S\&OP culture and leadership) disinterest is a major reason for the failure of stakeholders' integration and the lack of meetings (S\&OP Organization). S\&OP Process, data and IT (S\&OP tools and data) are required to optimize business profit (performance management)[2]. Regarding the A\&SOP process model, the risk of failure is as much as in S\&OP. But it seems necessary to try to detail this model, for example on the link with DDS\&OP. Similarly, A\&SOP is based on the simulation of optimistic, pessimistic and median strategic scenarios, and this requires a dedicated IT, which does not completely exist yet. These links and specificities can make AS\&OP and S\&OP approaches successfully reach a high stage of maturity. 


\subsection{Point of Vigilance}

DDI experts on AS\&OP develop analogies with the concept of S\&OP in a grid at different levels of maturity [12]. On the basis of our understanding we can make some recommendations for both scholars and practitioners as a set of points of vigilance.

- For S\&OP, the formalization of a global point of view is good, but to allow a successful implementation, developing a detailed approach will be a plus;

- Little information is given by DDI on how to make all the steps, from 1 to 6 (see Figure 3). The implementation of the S\&OP process is already difficult, the AS\&OP model of flows needs to be clarified/explained;

- Step 6 links AS\&OP and DDS\&OP. The positioning of buffer (stock, time, capacity) or control point, but also the definition of families and other information required by the DDS\&OP process also needs to be clarified specifically such as to achieve a successful implementation of the vertical alignment between AS\&OP and DDS\&OP;

- Regarding S\&OP tools and data, they need to be supported with relevant data that require dedicated software. Studying and developing these software and decision support systems seem to be mandatory. Otherwise, the AS\&OP may have unrealistic goals (to carry out long-term simulations of optimistic, pessimistic and median scenarios);

- Concerning performance management, more studies on the benefits and limits of this choice of metrics (i. working capital, ii. contribution margin, iii. customer base) can be done in order to demonstrate their value, compared to existing flowbased metrics.

\section{Conclusion and Further Research}

In this paper, we focused on decision support processes for strategic collaborative manufacturing activities. We argued that usual approaches are based on tools that were developed a long time ago and which seem not to be relevant anymore. At the same time, new proposals have recently appeared on the market to address this issue, but no scientific study has been developed to assess their benefits and limits.

Therefore, we have presented and discussed in this paper a structured comparison between the S\&OP and AS\&OP concepts. Our findings show that in terms of goals, AS\&OP and S\&OP are quite similar. But on the issue of coordination, AS\&OP includes real and significant novelties compared to the traditional S\&OP approach and has a better potential for success However, lack of scientific studies on DDAE, DDMRP and especially on AS\&OP allow us making only partial conclusions on the real benefits of AS\&OP. Given that our results can be considered as preliminary, further research is still needed.

An extension of this research might consist in improving the framework of the analysis, which allowed only a comparison with a large mesh as well as including additional criteria as analysis axes. [9] for instance showed the relevance of including finer study parameters to better understand the concept of S\&OP and consequently of 
AS\&OP. Another perspective could be on an objective assessment of AS\&OP implementation (the first ones are ongoing and not yet finished) results compared to those of S\&OP. We could, in view of the craze of practitioners for DDAE, take advantage of the future experiences to study in more depth the specifics of AS\&OP. Lastly, future research works should consist in developing a kind of AS\&OP maturity model that end-users can use to improve their performance.

\section{References}

[1] P. Hadaya et L. Cassivi, « The role of joint collaboration planning actions in a demanddriven supply chain », Ind. Manag. Data Syst., vol. 107, nº 7, p. 954-978, aug. 2007.

[2] N. Tuomikangas et R. Kaipia, «A coordination framework for sales and operations planning (S\&OP): Synthesis from the literature », Int. J. Prod. Econ., vol. 154, p. 243-262, aug. 2014.

[3] J. A. Grimson et D. F. Pyke, « Sales and operations planning: an exploratory study and framework », Int. J. Logist. Manag., vol. 18, nº 3, p. 322-346, nov. 2007.

[4] D. Ling et A. Coldrick, « Breakthrough Sales \& Operations Planning: How we developed the process. ", p. 39.

[5] R. C. Ling et W. E. Goddard, Orchestrating Success: Improve Control of the Business with Sales \& Operations Planning. Wiley, 1989.

[6] T. F. Wallace, Sales and Operations Planning: The How-To Handbook. Steelwedge Software, 2008.

[7] «APICS 2017 | APICS Event». available on: http://www.apics.org/credentialseducation/events/event-landing-page/2017/10/15/default-calendar/apics-2017.

[8] A. M. Tavares Thomé, L. F. Scavarda, N. S. Fernandez, et A. J. Scavarda, " Sales and operations planning: A research synthesis ", Int. J. Prod. Econ., vol. 138, n 1, p. 1-13, jul. 2012.

[9] J. Kristensen et P. Jonsson, "Context-based sales and operations planning (S\&OP) research: A literature review and future agenda », Int. J. Phys. Distrib. Logist. Manag., vol. 48, nº 1, p. 19-46, jan.. 2018.

[10] L. Lapide, «SALES AND OPERATIONS PLANNING PART I: THE PROCESS », p. 3 , 2004.

[11] P. Jonsson et J. Holmström, «Future of supply chain planning: closing the gaps between practice and promise », Int. J. Phys. Distrib. Logist. Manag., vol. 46, n 1, p. 62-81, jan.. 2016.

[12] « Demand Driven Adaptive Enterprise (DDAE)», The Demand Driven Institute - World Leader in Demand Driven Education. [En ligne]. Available on: https://www.demanddriveninstitute.com/demand-driven-adaptive-enterprise-m.

[13] R. Miclo, Challenging the "Demand Driven MRP» Promises: a Discrete Event Simulation Approach. Ph Thesis, Ecole nationale des Mines d'Albi-Carmaux, 2016.

[14] APICS, CPIM - Certified in Production and Inventory Management | APICS. 2016.

[15] J. Jansson et F. Åberg, Sales and operations planning in the process industry: A diagnostic model. 2014.

[16] Wight, O. (1995). The executive's guide to successful MRP II (Vol. 6). John Wiley \& Sons. 